\title{
PERANCANGAN MEDIA INFORMASI PENGENALAN PERAHU PINISI DI KABUPATEN BULUKUMBA
}

\author{
Astuti Ramdani, Agussalim Djirong, Aswar \\ Desain Komunikasi Visual Fakultas Seni dan Desain Universitas Negeri Makassar \\ daraptuti@gmail.com \\ agussalim_djirong@yahoo.co.id \\ aswarcadikong@gmail.com
}

\begin{abstract}
ABSTRAK
Perancangan ini berangkat dari permasalahan kurangnya minat masyarakat khususnya remaja mengenai warisan budaya yaitu perahu Pinisi yang terdapat di kabupaten Bulukumba disebabkan oleh informasi yang tersedia kurang menarik minat audiens juga terhadap teks yang monoton, sehingga warisan budaya ini khususnya mengenai makna filosofis dalam ritual pembutannya akan jarang dikenal oleh bangsa sendiri. Hal inilah yang mendasari perancangan media informasi ini. Perancangan ini bertujuan untuk menghasilkan media informasi yang inovatif, komunikatif serta menarik dengan informasi yang padat dan jelas namun tidak begitu panjang agar audiens tidak merasa bosan. Materi disusun berdasarkan data yang diperoleh dari buku dan fasilitas internet (Studi pustaka), hasil wawancara langsung dari panrita lopi, Observasi pada lokasi pembuatan perhu di Bonto Bahari serta Dokumentasi. Yang kemudian di analisis dengan menggunakan metode analisis $5 \mathrm{~W}+1 \mathrm{H}$. Dalam perancangan media informasi hal yang dilakukan dalam konsep perancangan yaitu, menyusun materi/pokok bahasan, memuat brainstorming dan mind mapping, membuat storyline, membuat storyboard, membuat sketsa, dan implementasi digital. Sebagai penunjang media utama, maka dibuatlah media pendukung agar dapat lebih membantu penyebaran informasi.
\end{abstract}

Kata Kunci: Perahu Pinisi, Bonto Bahari, Makna Filosofis, Media Informasi.

\section{PENDAHULUAN}

Kebudayaan merupakan identitas bangsa. Hal ini menunjukkan betapa kebudayaan merupakan aspek yang sangat penting bagi suatu bangsa. Karena kebudayaan menunjukkan jati diri bangsa itu sendiri (Direktorat Kebudayaan, 2010). Perahu Pinisi adalah perahu khas suku Bugis dan Makassar di Sulawesi Selatan yang telah ada sejak abad keempat belas, pada awalnya dibuat untuk keperluan angkutan antar pulau, sebagai alat transportasi untuk merantau dan keperluan menangkap ikan. Umumnya perahu ini memiliki tujuh buah layar yang menandakan 7 ayat surah Al-Fatiha, yaitu tiga diujung depan, dua di depan serta dua di belakang yang merupakan tiang layar utama yang menandakan 2 kalimat syahadat. Perahu Pinisi merupakan sebuah warisan budaya nenek moyang bangsa Indonesia yang mencirikan identitas bangsa sebagai bangsa Bahari. Keahlian pembuatan perahu terbatas hanya masyarakat Ara, Lemo-lemo dan Bira.
Hal ini sangat erat kaitannya dengan lagenda yang tersebar diluar sana. Dahulu kala ada perahu yang dikenal dengan perahu Sawerigading yang merupakan perahu milik seorang yang sangat sakti. perahu tersebut lunasnya terdampar di pantai Ara, Sottingnya terdampar di Lemo-lemo, sedangkan layar dan tali temalinya di Bira. Oleh karena itu keahlian membuat perahu hanya dimiliki oleh penduduk yang tinggal di daerah, dimana terdapat bagian dari perahu Sawerigading yang rusak tersebut.

Dalam proses pembuatan perahu pinisi, para pengrajin perahu pinisi memiliki ritual dalam pembuatannya mulai dari harus menghitung hari baik untuk memulai pencarian kayu sebagai bahan baku yang biasanya jatuh pada hari kelima dan ketujuh pada bulan yang berjalan. Selanjutnya kepala tukang (Punggawa) memimpin pencarian kayu. Untuk kondisi sekarang, untuk mendapatkan kayu dengan cara membeli kepada penjual kayu. Selanjutnya proses peletakan lunas (kayu dasar) perahu dimulai, dengan meletakkan lunas menghadap Timur 
Laut kemudian disiapkan sesajen berupa kuliner yang manis-manis. Sajian kudapan yang manis merupakan simbol harapan agar perahu yang hendak dibuat akan mendatangkan keberuntungan bagi pemiliknya.

Keahlian pembuatan perahu terbatas hanya masyarakat Ara, Lemo-lemo dan Bira. Hal ini sangat erat kaitannya dengan lagenda yang tersebar diluar sana. Dahulu kala ada perahu yang dikenal dengan perahu Sawerigading yang merupakan perahu milik seorang yang sangat sakti. perahu tersebut lunasnya terdampar di Pantai Ara, Sottingnya terdampar di Lemo-lemo, sedangkan layar dan tali temalinya di Bira. Oleh karena itu keahlian membuat perahu hanya dimiliki oleh penduduk yang tinggal di daerah, di mana terdapat bagian dari perahu Sawerigading yang rusak tersebut.

Informasi mengenai perahu Pinisi dapat diperoleh dengan membaca artikelartikel di internet dan buku namun, seperti yang diketahui dan dirasakan saat ini minat membaca semakin berkurang terlebih lagi terhadap teks yang monoton. Sehingga informasi tentang perahu Pinisi semakin jarang diketahui oleh masyarakat khususnya mengenai makna filososfis yang terdapat di dalamnya. Padahal warisan leluhur ini merupakan sesuatu yang patut dipertahankan. Agar warisan budaya ini dapat terus dikenal dan bertahan hingga generasi-generasi yang akan datang maka dipandang perlu untuk membuat "Media Informasi Pengenalan Perahu Pinisi di Kabupaten Bulukumba" yang dapat menyajikan informasi dengan visualisasi yang menarik dan menumbuhkan minat remaja untuk memperoleh pengetahuan tentang perahu Pinisi.

Perancangan ini bertujuan untuk menghasilkan sebuah media informasi untuk masyarakat yang dapat menjadi pengantar atau pemantik untuk dapat mengetahui dan mengenal tentang perahu Pinisi di Sulawesi Selatan kabupaten Bulukumba agar warisan budaya ini dapat terus bertahan hingga generasi-generasi yang akan datang, serta membuat media yang dapat menyampaikan pesan secara efektif, komunikatif dan mudah diingat. Adapun manfaat dari penelitian/perancangan Secara teoritis perancangan ini bermanfaat memberikan sumbangsi informasi tentang makna filosofis dalam perahu Pinisi di Kabupaten Bulukumba. Adapun secara Praktis perancangan ini bermanfaat untuk menambah wawasan dalam hal penyajian informasi dan juga agar dapat membantu dalam memberikan referensi bagi generasi yang akan datang untuk mengenal perahu Pinisi agar warisan budaya ini dapat terus dipertahankan.

Adapun penelitian yang relevan dengan perancangan media informasi yang akan dibuat yaitu Media Informasi Interaktif Wisata Budaya Kabupaten Pacitan Berbasis Multimedia. Penulis dalam jurnalnya, melakukan perancangan menggunakan analisis dengan melakukan observasi pada masyarakat Kabupaten Picitan yang belum mengenal wisata budaya lokal. Kemudian penulis membuat karangka pikir yang kemudian dilanjutkan dengan perancangan setiap halaman dalam media informasi dan menentukan materi yang dimuat dalam setiap halaman tersebut. Dalam pembuatan media informasi interaktif berbasis multimedia tersebut, penulis menggunakan Adobe Flash CS3. Fasilitas yang ada dalam media informasi interaktif berbasis multimedia ini antara lain memuat informasi upacara adat unggulan dari tiap kecamatan di Kabupaten Pacitan, foto-foto serta video (Sandy, W. M., Maryono, \& LiesYulianto. 2015)

Perancangan Video Infografi "Noken, Warisan Budaya Tak Benda Papua. Dalam penelitian ini yang digunakan adalah Analisa Swot Strength (Kekuatan) Video ini membahas tentang warisan budaya Noken Papua yang masih jarang dikemas dalam bentuk video infografik, menggunakan nuansa flat design yang sederhana sehingga setiap informasi dapat tersampaikan dengan baik. Weakness (Kelemahan) ada kemungkinan bagi audience untuk perlu memiliki pemahaman yang lebih, karena disajikan dalam bentuk ilustrasi vektor yang tidak realistik dan durasi yang cukup singkat. Opportunities (Peluang) Pembahasan mengenai warisan budaya Papua yang masih 
jarang sehingga ada peluang untuk dapat menarik perhatian audience, berkembangnya teknologi yang terbukti nyata dengan adanya internet dan media elektronik juga dapat membuat penyebaran informasi mengenai video infografik ini akan lebih mudah disaksikan. Threat (Ancaman) persaingan dengan media lain seperti video dokumenter atau buku yang sifatnya berbeda. Adapun Perancangan Komunikasi Visual Media Utama, proses ini dimulai dari pembuatan ide dan konsep, dilanjutkan dengan pembuatan storyboard dan sketsa untuk dijadikan gambaran dalam menentukan gerakan di setiap scene (Nathania, Hidajat, H., \& Alethea. 2016).

Aplikasi Multimedia Sebagai Media Informasi Pada Pengenalan Monumen Yogya Kembali Yogyakarta. Penelitian ini menggunakan Analisis kebutuhan sistem, yaitu menganalisis kebutuhan sistem yang disesuaikan dengan kebutuhan pengguna. Adapun metode perancangan sistem yaitu untuk menganalisa rancangan sistem untuk menyusun sistem yang baru dan menggantikanya sistem yang lama baik secara keseluruhan atau hanya memperbaiki sistem yang ada. Perancangan sistem meliputi merancang konsep, merancang isi, merancang naskah, merancang grafis (Murinto, \& Effendi, Z. 2014.).

Perancangan adalah penggambaran, perencanaan dan pembuatan sketsa atau pengaturan dari beberapa elemen yang terpisah ke dalam satu kesatuan yang utuh dan berfungsi Perancangan sistem dapat dirancang dalam bentuk bagan alir sistem yang merupakan alat bentuk grafik yang dapat digunakan untuk menunjukan urutan-urutan proses dari sistem (Syifaun, 2003:2).

Pada pengertian lain, mendeskripsikan perancangan sebagai proses banyak lagkah dimana representasi-representasi data dan struktur program, karakteristik-karakteristik antar muka, dan rincian procedural diikhtisarkan dari hal-hal yang berkaitan dengan kebutuhan-kebutuhan informasi.

(Mansueto \& Joseph, 2005:5) menyatakan bahwa: "Perancangan adalah proses untuk membuat keputusan tentang apa yang perlu dilakukan oleh organisasi".

Menurut (Jugiyanto, 2005:8) "Informasi adalah data yang telah diolah menjadi bentuk yang lebih berarti dan berguna bagi penerimanya untuk mengambil keputusan masa kini maupun masa yang akan datang.". Maksud dari kata data itu sendiri adalah fakta atau kenyataan yang sebenarnya. Pengertian informasi juga dapat di definisikan sebagai hasil dari pengolahan data dalam suatu bentuk yang lebih berguna dan lebih berarti bagi penerimanya yang menggambarkan suatu kejadian-kejadian (event) yang nyata (fact) yang digunakan untuk pengambilan keputusan.

Media akan mengarahkan kita pada apa yang harus kita lakukan. Media juga memberikan berbagai gagasan, sedangkan masyarakat akan mengikutinya. Asumsi dari teori ini adalah media mempunyai kemampuan untuk menyeleksi dan mengarahkan perhatian masyarakat pada gagasan tertentu. Media mengatakan pada kita apa yang penting dan apa yang tidak penting (Nuruddin, 2007:105).

Menurut (Poerwadarminto 1976:369) “ identifikasi adalah penentuan atau penetapan identitas seseorang atau benda". Menurut ahli psikoanalisis identifikasi adalah suatu proses yang dilakukan seseorang, secara tidak sadar, seluruhnya atau sebagian, atas dasar ikatan emosional dengan tokoh tertentu, sehingga ia berperilaku atau membayangkan dirinya seakan-akan ia adalah tokoh tersebut. Berdasarkan pendapat di atas, dapat ditarik kesimpulan bahwa identifikasi adalah penempatan atau penentu identitas seseorang atau benda pada suatu saat tertentu.

Dalam buku Seni Ilustarasi oleh Sofyan Salam, menuliskan bahwa seni ilustrasi merupakan niat ilustarator untuk mengomunikasikan secara visual dalam bentuk "gambaran grafis" suatu subyek (fakta atau opini) dengan maksud menjelaskan, mendidik, menceriterakan, mempromosikan, mengajak, menyadarkan, menghibur, menyampaikan pandangan, memperingati, memuliakan, mencatat peristiwa, menyampaikan rasa simpati atau empati serta 
berbagai kemungkinan maksud lainnya. (Salam, 2017:12)

Desain Komunikasi Visual merupakan bidang keilmuan yang bertujuan untuk menemukan solusi (pemecahan masalah) dalam ranah komunikasi visual, dengan metodologi tersendiri yang dilakukan melalui proses mendesain yang sistimatis, yaitu dengan pengolahan/penataan unsur-unsur rupa dalam suatu paduan yang khas menjadi "bahasa rupa/visual" yang menarik minat/perhatian, estetis dan mampu/mudah dipahami; di mana "bahasa rupa/visual" tersebut merupakan implementasi dari isi/materi pesan/informasi untuk dikomunikasikan kepada khalayak sasaran (target audiens/konsumen) yang menjadi sasaran komunikasi. (Said, Cahyadi, \& Arifin, 2017:7).

Sampai sekarang ini masih terjadi perbedaan pendapat mengenai asal mula nama pinisi. Dalam hal ini ada beberapa pendapat mengenai nama pinisi, yaitu: Menurut Usman Pelly dalam buku ara dengan perahu bugisnya, nama pinisi diduga berasal dari kata Venesia, sebuah kota pelabuhan di italia yang terkenal pada zamannya. Senada dengan pendapat tersebut, sebuah sumber menyebutkan bahwa yang dibuat pinisi ialah model layar (yang terdiri dari tujuh helai). Sumber lain berpendapat bahwa, nama pinisi diduga berasal dari kata panisi. Kata panisi (Bugis, artinya: sisip; mappanisi artinya menyisip). Mappanisi (menyisip) yaitu menyumbat semua persambungan papan, dinding, dan lantai perahu dengan bahan tertentu agar tidak kemasukan air. Dugaan tersebut berdasar pada pendapat yang menyatakan bahwa orang Bugis yang pertama menggunakan perahu pinisi. Lopi dipanisi' (Bugis), artinya perahu yang disisip. Diduga dari kata panisi mengalami proses fonemik menjadi pinisi. Pinisi adalah paduan teknologi dan budaya serta merupakan lambang keperkasaan suku Bugis-Makassar di lautan. Nama Pinisi berasal dari kata panisi. Kata panisi berasal dari Bugis yaitu Mappanisi artinya menyisip yaitu menyumbat semua persambungan papan, dinding dan lantai perahu dengan bahan tertentu agar tidak kemasukan air. Dugaan tersebut berdasar pada pendapat yang menyatakan bahwa orang Bugis yang pertama menggunakan perahu pinisi (lopi dipanisi) artinya perahu yang disisip. Dari kata panisi mengalami proses fenomik menjadi pinisi. Pinisi adalah perahu yang mempunyai tujuh layar dan memakai anjong pada haluan. (Saenong, 2013:177).

UNESCO resmi tetapkan perahu pinisi sebagai warisan dunia. Kabar gembira terutama bagi masyarakat Bulukumba ini, datang dari sidang ke-12 Komite Warisan Budaya Tak benda UNESCO di Jeju Island, Korea Selatan. Sidang berlangsung sejak 4 Desember 2017 dan berakhir pada 9 Desember 2017 di Jeju Island, Korea Selatan. Akhirnya pada Kamis, 7 Desember 2017, menetapkan usulan Indonesia, yaitu PINISI: Seni Pembuatan Perahu di Sulawesi Selatan (PINISI: Art of Boatbuilding in South Sulawesi) ke dalam UNESCO Representative List of the Intangible Cultural Heritage of Humanity. Penetapan ini, seperti dilansir galamedianews.com, merupakan bentuk pengakuan dunia internasional, terhadap arti penting pengetahuan akan teknik perkapalan tradisional yang dimiliki nenek moyang bangsa Indonesia, yang diturunkan dari generasi ke generasi dan yang masih berkembang sampai hari ini. (http://traveltodayindonesia.com/unesco-esmitetapkan-kapal-pinisi-sebagai-warisan-dunia/)

\section{METODE PENELITIAN}

Metode Perancangan merupakan cara berfikir dengan cara menyesuaikan rumusan masalah dan tujuan perancangan hungga menghasilkan suatu produk(hasil rancangan). Metode perancangan yang digunakan adalah metode deskriptif kualitatif yaitu untuk mendeskripsikan atau memberi gambaran pada obyek yag diteliti atau yang akan dirancang. Dalam metode ini meliputi pengumpulan data dan analisis data.

Pengumpulan data terdiri dari data primer yang merupakan data yang diperoleh secara langsung oleh penulis dan data sekunder yaitu data yang diperoleh secara tidak langsung atau merupakan hasil 
penelitian orang lain. Pengumpulan data yang dilakukan yaitu dengan Penelusuran/Kajian Pustaka Teknik ini digunakan untuk memperoleh data yang dikumpulkan melalui buku, serta fasilitas internet (maya) seperti jurnal dan dari beberapa artikel yang telah dikumpulkan yang relevan dengan perancangan yang merupakan data sekunder. Kemudian dilakukan Observasi, untuk memperoleh data primer, observasi dilakukan pada lokasi pembuatan perahu Pinisi di kecamatan Bonto Bahari, kabupaten Bulukumba, Sulawesi Selatan. Selanjutnya Wawancara, pengumpulan data yang dilakukan dengan memberi beberapa pertanyaan kepada narasumber data diperoleh dari Panrita Lopi (orang yang ahli dalam pembuatan perahu). Dokumentasi Teknik ini digunakan untuk memperoleh data visual atau verbal. Dokumentasi, dilakukan untuk memperoleh datavisual atau verbal pada saat melakukan penelitian di lokasi pembuatan perahu Pinisi.

Teknik analisa yang digunakan ialah analisa $5 \mathrm{~W}+1 \mathrm{H}$, untuk memperjelas permasalahan, materi dan target audience dalam perancangan media informasi ini; Setelah melakukan pengumpulan data dan analisa permasalahan maka selanjutnya ialah menentukan konsep desain dalam perancangan. Adapun konsep perancangan media Informasi ini ialah Bahari yang memiliki arti laut atau kelautan dan juga keindahan.

\section{HASIL DAN PEMBAHASAN}

Materi dalam media informasi ini terdiri dari materi awal yag memuat tentang pengenalan singkat tentang makna dari layar perahu pinisi, kemudian materi utama yang memuat tentang makna filosofis dari ritual pembuatan Pinisi yaitu ritual penebangan Lunas, ritual Annatara' (meratakan ujung lunas), ritual Ammossi' (pemberian pusat pada perahu) dan ritual Annyorong Lopi (peluncuran perahu ke laut). Serta materi akhir tentang penetapan Pinisi sebagai warisan tak benda oleh UNESCO. Dalam penyampaian materi tersebut dilakukan dengan pendekatan audio visual dengan memadukan unsur visual dan verbal/audio ke dalam satu media. Gaya visual dalam perancangan ini yaitu cartoon yang juga dipadukan dengan ilustrasi realis yang dirasa cocok dengan target audience yang dituju. Adapun penggunaan warna serta pemilihan tipografi disesuaikan dengan konsep desain yang telah diusung.

Target audiencenya ialah Remaja, usia 17-23 tahun, dengan jenis kelamin perempuan dan laki-laki, pendidikan SMA dan S1, serta kelas social menengah keatas.

Setelah melakukan analisa dilakukanlah perancangan desain dengan membuat storyline dan storyboard yang akan menjadi acuan dalam perancangan motion graphic ini. Storyboard terdiri dari 18 scene dengan perkiraan durasi kurang lebih lima menit. Adapun font yang digunakan dalam perancangan ini yaitu Ampera dan Times New Roman, yang masing-masing memiliki karakter dan tingkat keterbacaan yang baik.

Tahapan proses perncangan setelah melaului proses analisis data dan pembuatan storyline dan storyboard ialah proses sketsa kemudia digitalisasi sketsa terpilih yang akan dilanjutkan dengan pengeditan grafis menjadi motion yang bersamaan denga memasukkan suara narrator yang telah direkam sebelumnya dan berakhir pada proses rendering menjadi sebuah video.

Perancangan ini menghasilkan sebuah media informasi berupa Motion graphic dengan resolusi 1920x1080px. Motion graphic dipilih karena mudah di akses dan berbasis internet sehingga dapat dengan mudah tersebar dan disebar luaskan, serta update dan modern. Dalam pembuatannya digunakan program Adobe Photoshop dan Paint tool Sai untuk pembuatan ilustrasi serta Adobe After Effect untuk pembuatan motion.

Berikut ini merupakan proses desain dari perancangan media informasi ini. 

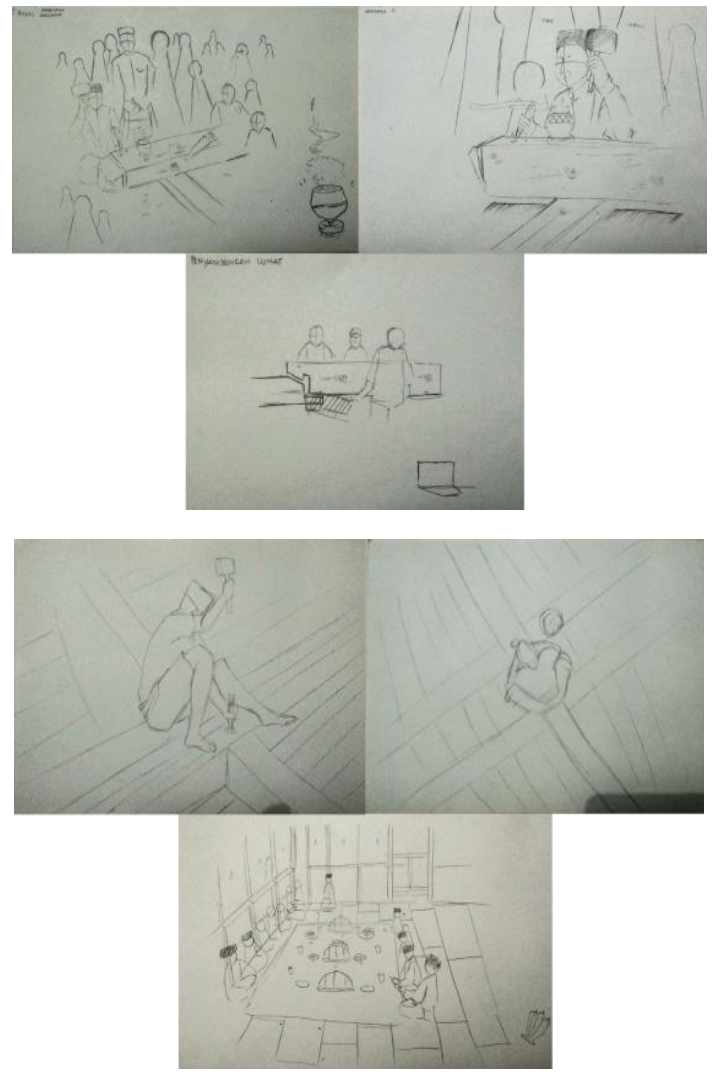

Gambar 1. Sketsa Perancangan

Setelah itu, sketsa terpilih akan dilanjutkan pada proses digitalisasi dengan menggunakan program Paint tool Sai dan Adobe Photoshop. Proses tersebut dapat dilihat dibawah ini.

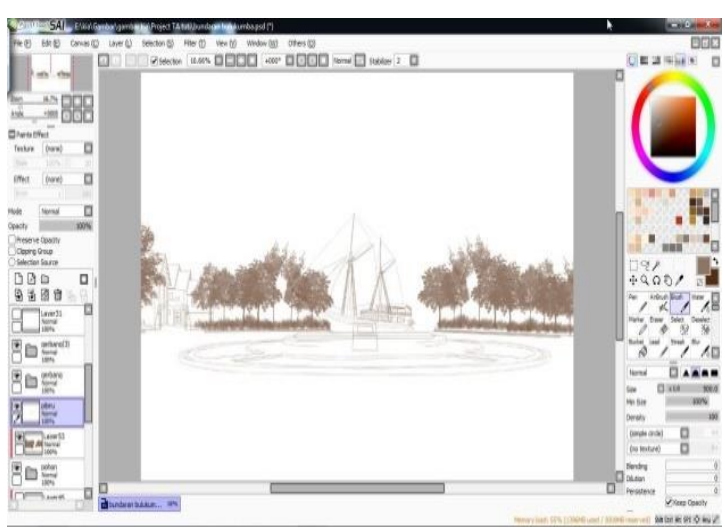

Gambar 2. Proses sketsa scene 1

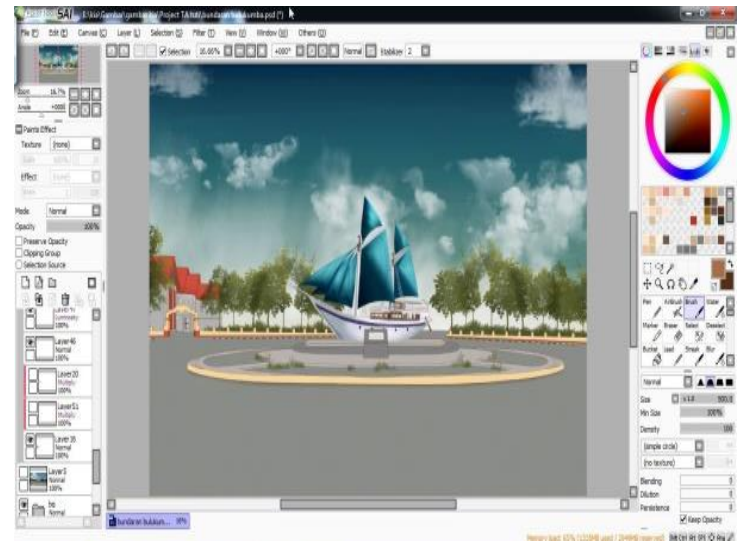

Gambar 3. Final scene 1

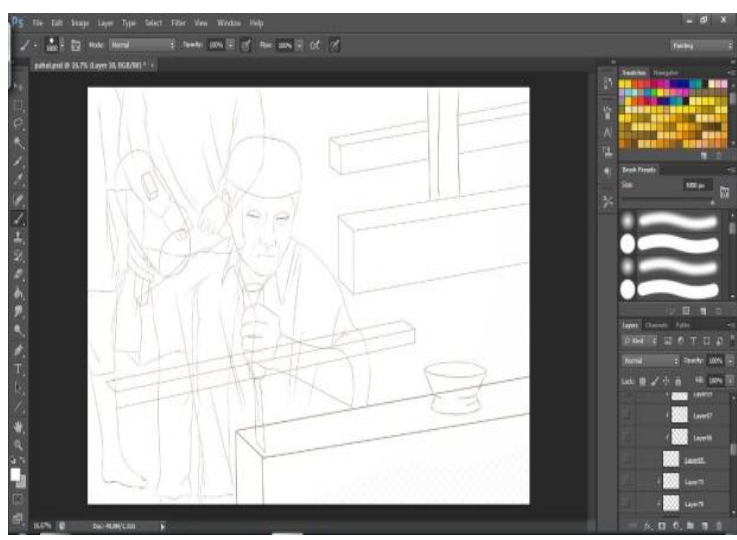

Gambar 4. Proses sketsa scene 11

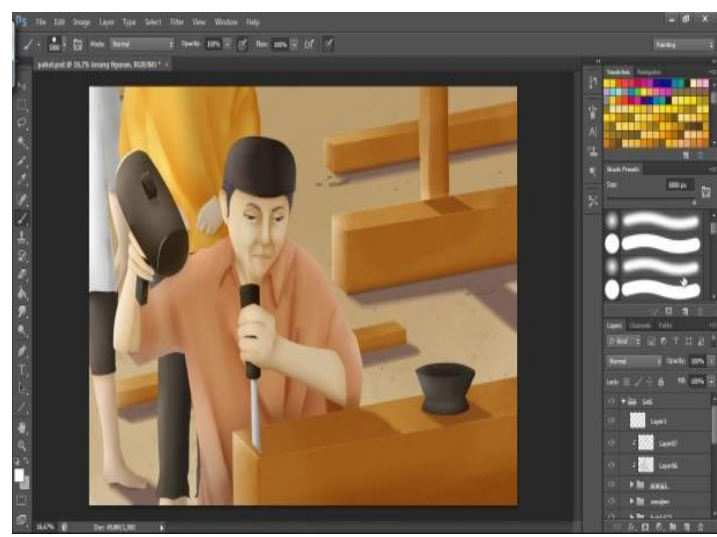

Gambar 5. Final scene 11 


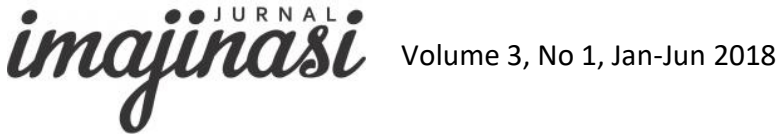

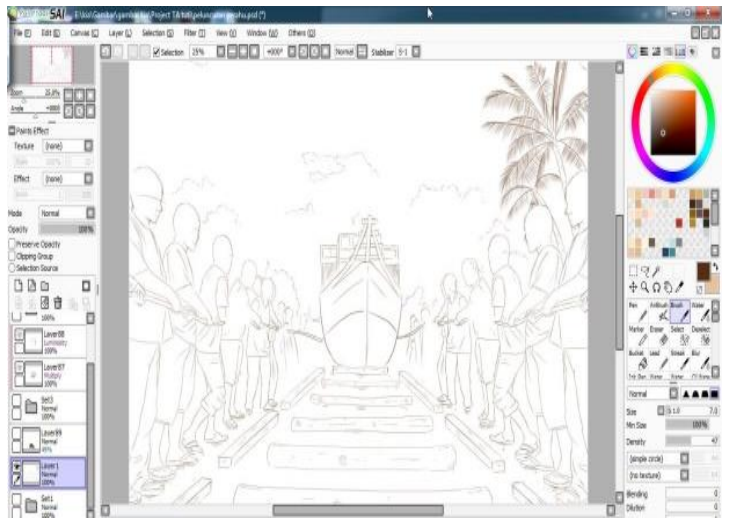

Gambar 6. Sketsa scene 18

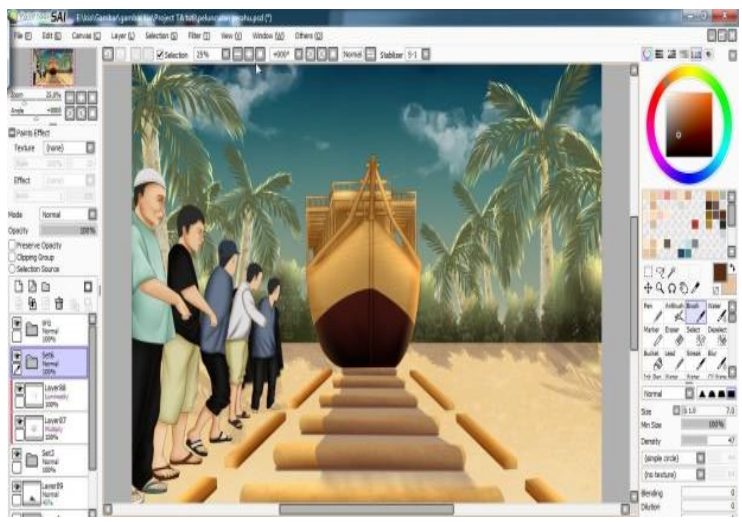

Gambar 7. Final scene 18

Setelah semua sketsa dibuat dan di digitalisasi maka, proses selanjutnya ialah pengeditan ilustrasi menjadi sebuah motion graphic dengan program Adobe After Effect.

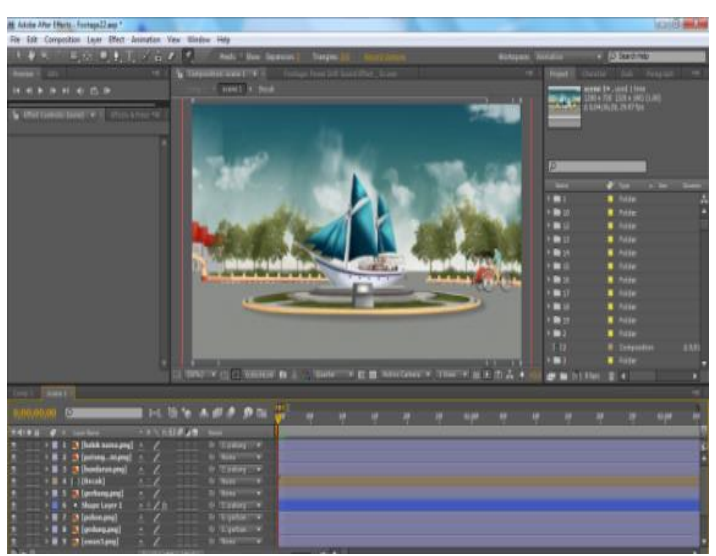

Gambar 8. Memasukkan background, Perahu dan becak pada scene 1

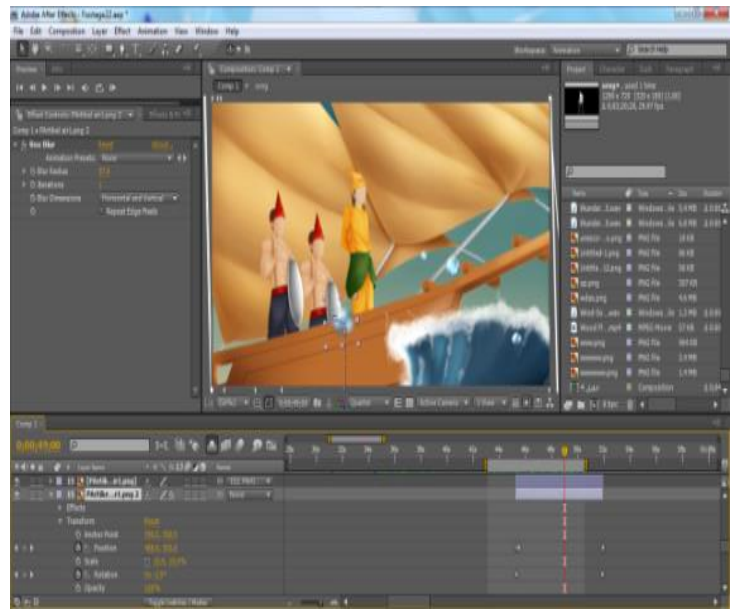

Gambar 9. Memasukkan setiap obyek pada scene 5 termasuk percikan air yang juga akan bergerak perlahan.

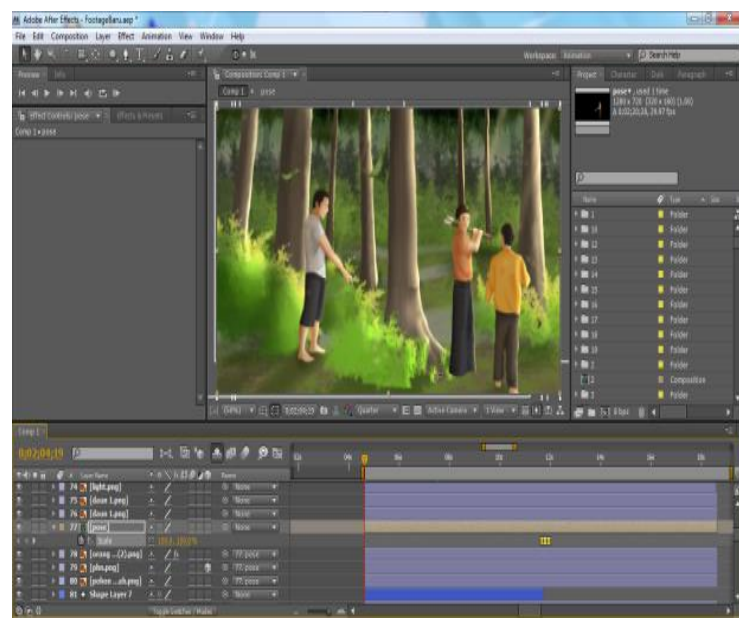

Gambar 10. Ritual penebangan Lunas perahu

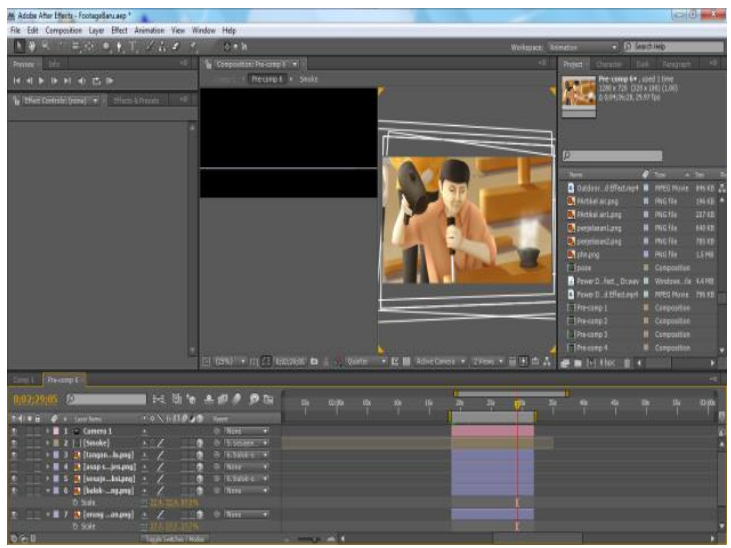

Gambar 11. Ritual Annatara' (meratakan ujung Lunas) 


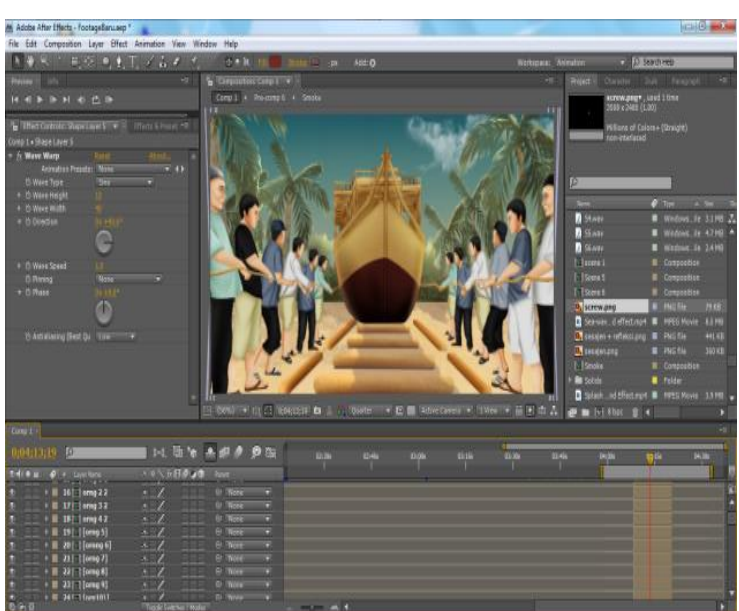

Gambar 12. Ritual Peluncuran Perahu

Format ilustrasi ini adalah Mp4 dengan resolusi 1920x1080px yang dapat di akses pada laptop maupun handphone, dengan durasi kurang lebih lima menit yang terdiri dari bumper, materi awal mengenai pengenalan dan sejarah singkat pinisi yang berkaitan dengan lagenda Sawerigading, materi utama mengenai makna filosofis dari beberapa ritual pembuatannya, materi akhir tentang penetapan perahu pinisi menjadi warisan tak benda oleh UNESCO. Setelah itu terdapat credit title.

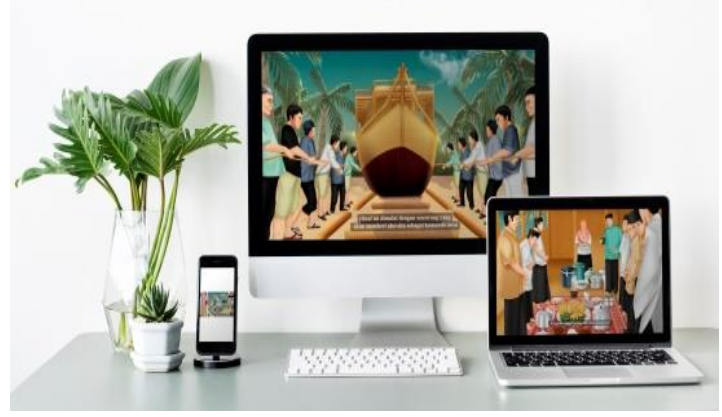

Gambar 13. Mock up hasil perancangan dalam beberapa media

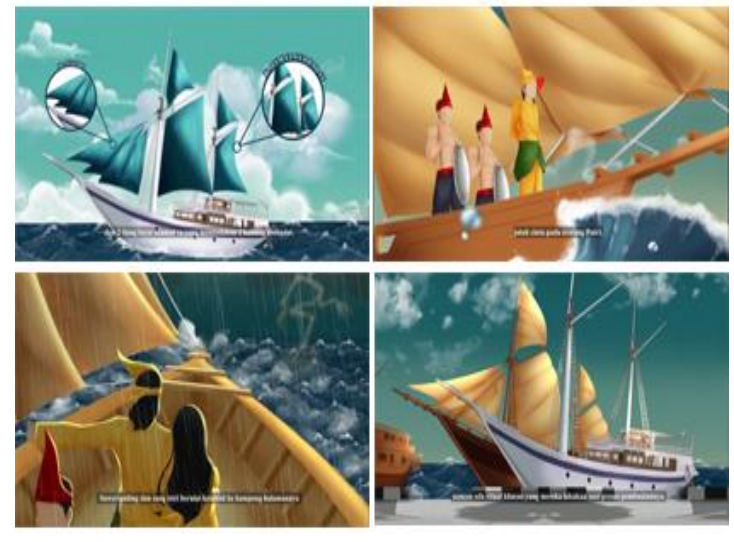

Gambar 14. Materi awal
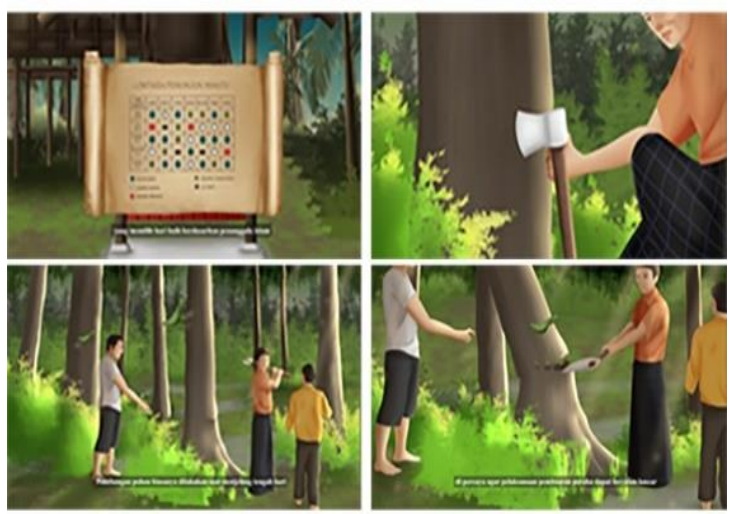

Gambar 15. Materi utama, ritual penebangan Lunas

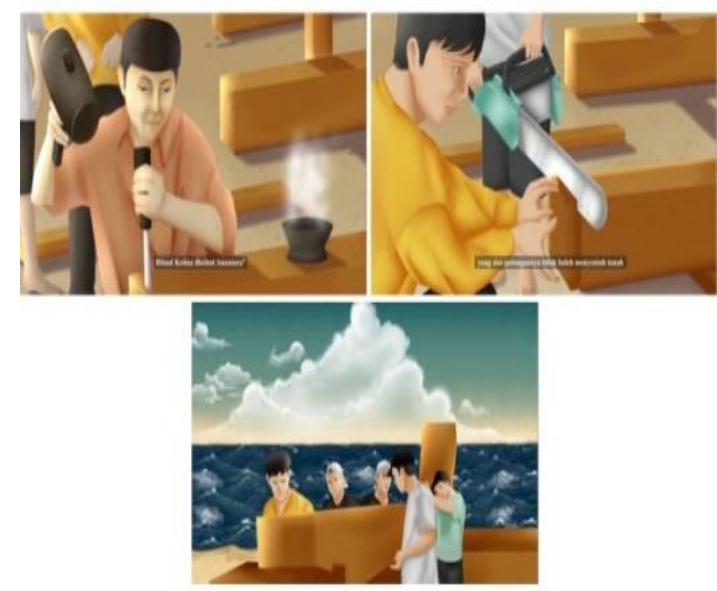

Gambar 16. Materi utama, ritual Annatara' 


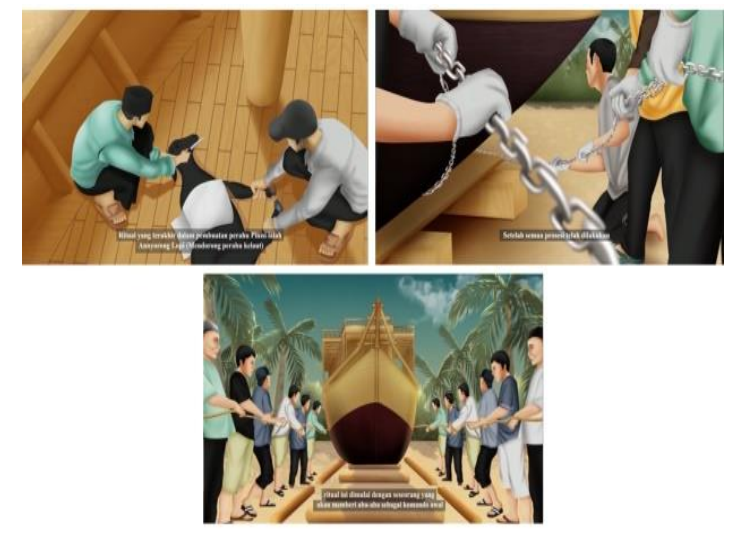

Gambar 17. Materi utama, Annyyorong lopi

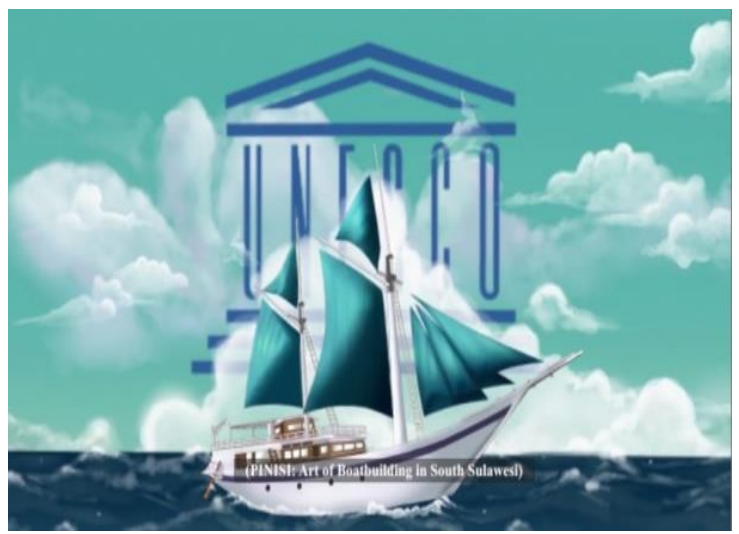

Gambar 18. Materi Akhir

Selain media utama dalam perancangan ini juga dibuat media pendukung yaitu: $\mathrm{X}$ Banner untuk mempublikasikan informasi media utama, USB Card/Flashdisk yang merupakan media pendukung yang menyimpan video motion graphic yang dapat dilihat melalui laptop maupun smart Tv, Tshirt, Gantungan kunci dan Tote bag yang merupakan souvenir sebagai media promosi hasil perancangan.

\section{KESIMPULAN}

Dari hasil perancangan media informasi video motion graphic makna filosofis perahu pinisi ini, di peroleh kesimpulan sebagai berikut:

1) Video Motion Graphic ini diharapkan dapat memecahkan masalah mengenai minat remaja untuk memperoleh pengetahuan mengenai warisan budaya. Materi yang dimuat dalam media informasi yang berupa video motion graphic ini yaitu mengenai makna filososfis dari beberapa ritual dalam pembuatan perahu pinisi yang disajikan secara ringan dalam artian mudah untuk dipahami.

2) Dihasilkan video motion graphic dengan durasi 5 menit 9 detik dengan resolusi 1366px $X 768 p x$ dengan muatan materi pengenalan perahu pinisi dan makna filosofis dalam beberapa ritual pembuatannya dengan visualisasi yang menarik serta suara Narator yang akan menjelaskan materi-materi tersebut.

3) Selain Media utama yang berupa video Motion Graphic juga dibuat media pendukung yaitu Flashdisk/USB Card yang didalamnya terdapat file video yang dapat langsung dilihat melalui laptop ataupun smart TV, kemudian dibuat juga media promosi yaitu X-banner, T-shirt, Tote bag dan Gantungan kunci.

\section{ACKNOWLEDGMENT}

Penghargaan dan terima kasih yang setulus-tulusnya kepada kedua orang tua saya tercinta yang telah mencurahkan segenap cinta dan kasih sayang serta perhatian moril maupun materil. Terima kasih yang setulus-tulusnya kepada Prof. Dr. H. Husain Syam M., TP. Selaku Rektor Univrsitas Negeri Makassar, Dr. Nurlina Syahrir, M. Hum. Dekan Fakultas Seni dan Desain Universitas Negeri Makassar, Drs. Abd. Azis Said, M.Sn. Ketua Prodi Desain Komunikasi Visual Fakultas Seni dan Desain Universitas Negeri Makassar, serta Bapak/Ibu Dosen Fakultas Seni dan Desain Prodi Desain Komunikasi Visual yang telah 
membimbing dan membekali ilmu pengetahuan kepada saya.

\section{REFERENSI}

Jogiyanto, H. M. 2005. Analisis dan Desain Sistem Informasi. Yogyakarta: Andi Offset.

Mansueto, \& Joseph. 2005. Pengurusan Teknologi. Malaysia: Universty Teknologi.

Murinto, \& Effendi, Z. 2014. Aplikasi Multimedia Sebagai Media Informasi Pada Pengenalan Monumen Yogya Kembali Yogyakarta. 1039-1050.

Nathania, Hidajat, H., \& Alethea. 2016. Perancangan Video Infografi Noken Warisan Budaya Tak Benda Papua. 66-75.

Nuruddin. 2007. Pengantar Komunikasi Massa. Jakarta: Raja Grafindo Persada.

Poerwadarminta, W. 1985. Kamus Umum Bahasa Indonesia. Jakarta Selatan: Balai Pustaka.
Saenong, M. A. 2013. Pinisi Paduan Teknologi dan Budaya. yogyakarta: Penerbit Ombak.

Said, A., Cahyadi, D., \& Arifin, I. 2017. Struktur Media Pembelajaran Dalam Perspektif Desain Komunikasi Visual. Makassar: UNM.

Salam, S. 2017. Seni Ilustrasi. Makassar: Badan Penerbit UNM Universitas Negeri Makassar .

Sandy, W. M., Maryono, \& LiesYulianto. 2015. Media Informasi Interaktif Wisata Budaya Kabupaten Picitan Berbasis Multimedia. 2-4.

Syifaun, N. 2003. Grafika Komputer. Yogyakarta: Graha Ilmu.

Palupi, \& Sandra. 2017. UNESCO Resmi Tetapkan Kapal Pinisi Sebagai Warisan Dunia. Travel Today Indonesia. 